\title{
Thinking about Edward Said: Pages from a Memoir
}

\author{
Gayatri Spivak
}

When I had contracted with the University of Massachusetts Press-in 1967 or 1968- to translate De la grammatologie, my editor sent me a copy of Edward Said's “Abecedarium culturae: Structuralism, Absence, Writing” that had just appeared in TriQuarterly and was later included as a chapter in Beginnings. It must have been 1971. Later that year I found out that my contract was with Hopkins and that J. Hillis Miller, who was then at Yale, and had already started organizing Derrida's U.S. career, had something to do with it. I never solved that puzzle. The editor at Massachusetts had stuck a note on the article, something like, What on earth is going on here? Perhaps he was beginning to realize, in giving me a contract for translating and introducing Jacques Derrida, that the press had bitten off more than it could chew.

Well, I read the piece. I had ordered Derrida off a catalogue, on impulse, not knowing his name, or anything about the French scene. It was a sort of self-help project, to which I still subscribe, shamefacedly. I have no general education, whereas Edward's piece seemed to be incredibly knowledgeable in just that way. I read the piece carefully, made notes in the margin, and filed it.

Those years were full of turmoil in my personal life, but I kept translating Derrida and kept teaching the "poststructuralists," who were all still writing. (I think I invented that ugly and imprecise word, a few years later, in my introduction to the Grammatology.) I sometimes think I developed a sort of comradeship with them precisely because I was so untutored, plugging away in remote Iowa City. "French" feminism, contained in the red covers of Elaine Marks and Isabelle de Courtivron's book, appearing in 1980, was a different matter entirely. The opening pages of this memoir, trying to 
touch my foremothers, will give a sense of the distance between that feminism and whatever I might call mine.

1971. I was to meet Derrida for the first time later that year. I am looking at my notes on Edward's article. Remember, I didn't know him or know of him either. I was not under his spell, as I later would be, like anyone who met him. I was only a dogged translator learning on the job, a patient and transfixed reader. I noticed this American's (nothing in the piece gave any other clue) impatient mistranslations. (It was much later that I would come to realize that this charming impatience was part of his signature.)

"Nothingness" for anéantissement, for example. That way, the ontology of annihilation could be rewritten as the "ontology of nothingness." Foucault's bold reversal of the process character of ontology-the philosophy that studies (coming into) being - could thus be controlled by way of a neat Sartrian displacement, moving the cursor to the second noun on Jean-Paul's title: Being and Nothingness. "Paralyze" for trahir_ "betray"—-so that a way of being meaning-ful without controlling meaning — carrying meaning, betraying it for others to read-could be presented as a general incapacity. "Significant" for signifiant_- "signifier," of course; "non-conscious" for inconscient_-"unconscious," of course; "the conditions and the forms of its contents" for les conditions de ses formes et de ses contenus, a real philosophical gaffe; and many more. "This smart man wants these people to mean something and he won't let them mean what they say-he is too impatient, he won't give them a chance," I wrote in the margin where Edward had written "structuralism is good public relations these days." It now seems inconceivable that he followed Steven Marcus in thinking that Foucault believed in dissociation of sensibility!

Translation is the most intimate act of reading. By then I was tight with grammatology. Looking at the notes now, it amuses me to see how much Edward was turned off by Derrida; Derrida's was exactly not his kind of charisma.

My supervisor at Cornell had been Paul de Man. From Cornell, he had moved to Johns Hopkins. In the early seventies, he and Hillis Miller moved to Yale and "the Yale school" got its start. Derrida got a visiting professorship contract there, and I went to Yale for as many of his lectures as I could.

1974 was a memorable year. At Yale I met both Edward Said and Jacques Lacan. I had not retained the name of the man who wrote "Abecedarum

Gay a tr i S P Iva k, Avalon Foundation Professor in the Humanities and director of the Center for Comparative Literature and Society at Columbia University, teaches English and the politics of culture. Her most recent book is Chotli Munda and His Asnow (2002). 
culturae." I did not connect it to the Byronic figure sitting alone all the way down on a narrow bit of vista that the old Naples Pizza in New Haven allowed. "Do you know him?" de Man asked and, when I said no, he said, "You should. He works on Foucault." De Man introduced us, then and there.

Our friendship prospered, mostly on the phone. I didn't read anything else by him for a long time. It was Palestine that we talked about and I was, of course, convinced. Some years ago, I had thrown myself heart and soul into the Bangladesh conflict. Strangely enough, I was even then unmoved by Indian nationalism. It seemed too grandiose, too much identified with great men and women in my immediate past. And, as a citizen, I was more critical of India's policy than otherwise, especially because, a year into my friendship with Edward, Indira Gandhi declared martial law and the young people joining the Naxalbari movement—a movement where peasants and intellectuals made common cause against rural and urban corruption and exploitation-were often tortured and murdered. I couldn't interest Edward in Indian politics. To the end this remained my regret. He was of course interested in India's struggle for independence and figures such as Gandhi and Nehru. He was immediately forthcoming when I asked him to write an introduction for Selected Subaltern Studies in 1987. He got on well with Ranajit Guha, founding editor of the collective. He was certainly friendly with the South Asians and South Asianists in and around Columbia. He regularly cotaught with Akeel Bilgrami.

Towards the end of his life, he and Mariam went to India, where Edward received two doctorates. His account of the trip to me did not seem to come from the friend who knew my deep and little-advertised concern for social justice in India. Early on in our friendship, looking back upon himself critically, he had described himself as a "playboy" before he woke up to the question of Palestine. (Who knows where one's stereotypes for oneself are hatched?) That word came to mind as I heard him speak about India. At any rate, our friendship (by then carried on as if Columbia University did not exist) received a dent from this. I was uneasy. In a while I sent word to him through our common friend Jacqueline Rose during what turned out to be the last days. He sent this back: "Ask Gayatri to make a gesture." There wasn't time.

But I am getting ahead of myself. During those early days, it was all about Palestine. I made speeches when asked and met interesting people, of whom I remember now Ibrahim Abu-Lughod, Nubar Hovsepian, and, of course, Eqbal Ahmed. In fact, the South Asia thing had an innocent repercussion there. Edward was political about Pakistan, as the eastern edge of West Asia (read, Middle East). He wrote not only for Al-Ahram (Cairo) and Al-Hayat 
(Arab journal out of London) but also for Dawn, the English-language Pakistani journal. But in that group of West Asians, Eqbal's Arabic was joshed a bit, in an altogether good-humored way, for its South Asian accent. He would turn to me and speak in Bengali, my mother tongue. For we were both born before the subcontinent was divided, and he was born in Purnia, in the neighboring state of Bihar, not very far from my hometown.

In those days I met Edward mostly at conferences. I remember "Politics of Interpretation" at the University of Chicago in 1981, where he made the important statement, in response to a particularly inept question, that he would be the first critic of the Palestinian state once it was established. (Later, I admired his principled stand against the beleaguered Arafat. Yet, with infinite political tact, he wrote little against the chairman except in the pages of Al-Ahram, whereas the so-called Oslo peace accords encountered his well-reasoned anger. Joseph Massad tells me that it was after Oslo that Edward got radicalized. That may well be. Even I understood that the false promise of Oslo started from a recoding of the situation of Israel-from a racist state to the only democracy in the Middle East.) Just recently, John Carlos Rowe has reminded us in the pages of the American Quarterly that I had taken Edward to task for not having sufficient sympathy for feminism, but I don't remember that. I did always remind him of feminism, remind him not to "take care of it" by making it one item on a list of worthy causes, or being nice to women, but that was between him and me. Am I right in thinking that he acknowledged at least my tenaciousness by telling the New York Times that I was the best postcolonial feminist?

Another big conference was the one at Essex, not "Europe and Its Others," but another one. I remember nothing of it but Edward and me walking across a sunlit grassy slope, a step ahead of Talal Asad, whom I had just met. Edward ruffled my hair and said, "We are on show here." At a conference in Marquette, he "played for me" on a hopelessly out-of-tune piano in the corner of the hall. I will never forget those sweet moments. I think it was a way of presenting alliance in those days when it did not exist in the United States academy between people from different parts of Asia. Also, it was just a way of enjoying those gigs. We were not jaded yet. He would give me advice on clothes, as I'm sure he gave many of his friends. He told me to stop wearing saris, and he was right, I think. It turns people off. But I was scared of reformatting my body for Western clothes alone, and things remained the same.

Our friendship prospered on the conference circuit. Not too many people thought the way we were thinking then. The postcolonial faction was not yet clearly distinguished from the theory crowd. I used to say that I was the chick vocalist on the theory-performing band: Stanley Fish, Fred Jameson, Edward Said, Hayden White, give or take a few; but I was always there. 
It was at the School of Criticism at Northwestern in 1982 that our friendship thickened. It seems portentous now. Something began and something ended. That was the last time I saw de Man. He came to my apartment, helped me pack-he was an immensely generous and nonhierarchical gossipy man (I was gobsmacked by the wartime letters when they were shown to me in an attic in Belgium five years later)—and walked me-somewhere, I forget, bus station? It is the leave-taking in the middle of the street that I remember, and remember thinking, the whites of his eyes are yellow! I took off for Britain and came back a few days later. He had collapsed and been flown back to New Haven, soon to be diagnosed with liver cancer.

That was the time of the Israeli massacre of the Palestinian refugees in Sabra and Shatila. Edward felt alone, surrounded by colleagues whose minds were occupied with the here and now of the school, with the politics of the academy. We were an island of two. He talked, I listened.

And so it went. We did public appearances together, for Palestine. In 1983, at the "Marxist Interpretation of Culture" conference in ChampaignUrbana, he could not himself attend, but suggested that we invite a man who had formerly worked for the Bertrand Russell Foundation to speak on behalf of Palestine. I came to New York often, saw him, had long conversations. I remember them all, but two or three occasions stand out. Once he was enraged. A colleague had accused him of anti-Semitism because he had called Farakhan "a Black Begin." Mariam came in in the middle of this conversation, and Edward pointed an agitated finger at me- "Ask her, ask her!" I remember Mariam completely deflecting the conversation and calming him down by taking it away from the entire dispute, saying, "She has a name!" Another time, in December of 1985, it was his fiftieth birthday. Mariam was cooking a meat dish in the kitchen. I had come in from out of town hoping I could have lunch with Edward. "See if you can get him to go to lunch," said Mariam. "It is his fiftieth birthday. He is so angry at being fifty that he refuses to go to dinner with me." Of course we did not go to lunch. I exchanged a few pleasantries with a gloomy Edward and went off to eat alone.

When I think of that day now I also think of the way he acknowledged his last, long, drawn-out illness. I remember his son, Wadie, mentioning that when speech left him, he was still rolling his eyes humorously at the moaning and groaning of the patient in the next bed. This stark contrast of impatience with friends and family, combined with great courage, was a characteristic of Edward Said.

I recall two particular instances of his support. In 1982 I managed to get a job offer from a reputable university in the U.S. Southeast. An embittered applicant had said to him: "She got it because she is a Third World woman." And Edward: "Not on that level." In 1988, when a couple of younger col- 
leagues trashed me as a racist because of a protocol mistake, Edward sent a message on his own, saying, "Gayatri works for the oppressed, stop this." I was immensely grateful that he had somehow drawn me into what was surely his life-working for the oppressed.

I came to Pittsburgh in 1986. "You're inching your way to the East Coast," he said. I took it with a laugh, as I had to take the dry, sly, acute humor he kept reserved for friends.

I think he often thought I was a fool, to be so persuaded by "theory." His stand, as president of the Modern Language Association, against pretentious and obscure language was against me as well. I think I tried his patience precisely because he cared. I sat next to him on the plane coming back from the Chicago MLA, where he had excoriated unnamed but easily recognizable persons who wrote fatuously obscure books. I asked him why he had so trashed me at the MLA; it was transparent. He said, altogether unconvincingly, and he knew it as he said it, that it wasn't about me-and he named an eminent "French feminist." And he was amused by my on-theground political commitments that had to be different from his, for they were "post"-colonial. "The first critic of the state of Palestine," I had heard him say in 1981. My idea of practical usefulness-I was no stateswomanwas to show the state the usefulness of a different kind of teacher training for the largest sector of the electorate. It seemed such a difficult project, so different from most literacy or science efforts, that I kept quiet about this for the first ten years or so and finally opened my mouth by a happenstance that I will describe in my memoirs. So, anyway, when Edward would ask, "Gayatri, what do you do when you go to those villages?" I would give the usual answer, "Hang out" (Mitwegsein, suspend previous training in order to train yourself, you know). The answer was not satisfactory.

These differences in intellectual style fostered our friendship. Until I came to Columbia, in 1991. We were not just ourselves any longer, but also connected to groups. And his connections had history. I was never the Saids' guest once I settled in New York. Yet something lingered, in private conversations, sometimes political, sometimes not. I have tried to give you a sense of whatever it was that moved us to con-verse, to turn together.

When I came to Columbia, I had already taught full-time for twenty-six years, moved up though the ranks, mostly at state universities, but for Emory (and I didn't like it there). I'd said to the Columbia student newspaper when I arrived that I had not taught at an elite school and did not know how I would fare. Edward thought that was disingenuous. Columbia was his element; he began and ended his forty-year teaching career here. I am still learning how to build at Columbia, inching toward effectiveness, I hope. 
These pages are part of a memoir that, according to Tariq Ali at least, Edward said I should write. I have called the book, If Only . . , translating a phrase from Assia Djebar's wonderful essay "Forbidden Gaze, Severed Sound." The title seems particularly apposite when I think of the walk I walked with Edward W. Said.

Now that he is dead, people about whom he was at best dubious, and mere sycophants, tell us about the political discussions he had with them. The celebrated dead belong to everyone. I have said only personal things. Intellectually, I wanted to fill out his view of the secular intellectual precisely from the from-above/from-below differences that I recounted a bit ago. That essay has found its place in the "secularism" issue of Boundary 2, edited by Edward's beloved student Aamir Mufti. And I will read the phrase "relative autonomy," with reference to art, that is in his posthumous book $\mathrm{Hu}$ manism and Democratic Criticism when there is a moment between deadlines.

Otherwise I chant that wild hymn, from the time when Hinduism was nearly indistinguishable from animism: as the ripe fruit bursts its skin, so immortality bursts out of death. In the love of family and friends, the intellectual journey of students. But also, harshly, literally, pushing up the daisies. In the face of that harsh immortality, the heart must break. 